\title{
ЗАСТРОЙЩИКИ, ПАРТИЯ ВЛАСТИ И НЕМНОГО КОНКУРЕНЦИИ В РОССИЙСКИХ МИЛЛИОННИКАХ: тИПОЛОГИЯ ГОРОДСКИХ РЕЖИМОВ В 2010-е rr.
}

\begin{abstract}
Взаимодействия ключевых акторов в городах, которое описывают с помощью концепта городского режима- важное структурное условие, определяющее логику городских конфликтов. Классические определения городского режима предполагают наличие широкой локальной автономии, что является базовым условием его формирования. Российские крупные города существуют в авторитарном контексте и сильно зависят от государственной власти. Это сокращает возможности для идентификации специфических городских режимов, существование которых в первую очередь предполагает наличие собственной повестки и реализацию своих политических курсов. Но крупные города сохраняют разнообразие политических, экономических и социальных условий, которые могут служить источниками разнообразия местной политики. В статье мы показываем вариацию городских режимов во всех российских миллионниках (за исключением Москвы и Санкт-Петербурга) и предлагаем их типологию. Мы опираемся на данные о составах городских ассамблей в период с 2012 по 2020 гг, а также на материалы СМИ. Базовая идея типологии - это оценка степени конкуренции политических и экономических групп. Для типологии городских режимов мы используем два критерия: степень фрагментации бизнеса и степень политической кон-
\end{abstract}

Всеволод Дмитриевич Бедерсон - к.полит.н., ст.н.с., Социологический институт РАНфилиал ФНИСЦ РАН; ст.н.с., Центр сравнительных исторических и политических исследований, Пермский государственный национальный исследовательский университет, Пермь, Россия. Электронная почта: vsbederson@gmail.com

Ирина Константиновна Шевцова - к.полит.н., ст.н.с., Социологический институт РАНфилиала ФНИСЦ РАН; директор, Центр сравнительных исторических и политических исследований, Пермский государственный национальный исследовательский университет, Пермь, Россия. Электронная почта: irinashevtsova@comparativestudies.ru 
куренции. В большинстве случаев мы наблюдаем политически неконкурентные режимы с фрагментированным («соревновательный авторитарный порядок») или нефрагментированным бизнесом («закапсулированный режим»), где бизнес преимущественно связан с партией власти. Только в одном случае сохраняется политическая конкуренция при наличии разнообразия бизнес-групп («состязательный режим»), а в ряде случаев политическая конкуренция сочетается доминированием одной бизнес-группы («конфронтационный режим»).

Ключевые слова: городской режим, локальная политика, конфликты, бизнес, партия власти

DOI: $10.17323 / 727-0634-2021-19-2-285-300$

Взаимодействия ключевых городских акторов, лежащие в основе городского режима,- структурное условие, определяющее динамику городской политики. Классические определения городского режима, появившиеся в результате исследования американских городов, предполагают, помимо прочего, высокую степень автономии последних, что и позволяет создавать собственную местную повестку (Logan, Molotch 1987; Stone 1989). Российские крупные города обладают низким уровнем политической и экономической автономии и, существуя в авторитарном контексте, зависят от государственной власти. Это сокращает возможности разнообразия городских режимов (Ледяев 2006), которые в первую очередь предполагают реализацию своих политических курсов. Вместе с тем крупные города сохраняют многообразие политических, экономических и социальных условий, которые могут служить источниками режимных разнообразий.

Исследования городских режимов в российских городах являются редкостью (искл., Пустовойт 2019; Чирикова, Ледяев 2019). Однако эта проблематика важна, поскольку властные коалиции, на которых базируется понятие городского режима, понимаются структурным условием, определяющим динамику городской политики и ее результаты: от возможностей управления, которыми располагает город (Stone 1989), до результатов разрешения городских конфликтов (Тыканова, Хохлова 2015). Несмотря на повсеместное сокращение автономии городов, они по-прежнему отвечают за реализацию множества политических решений. Поэтому понимание специфики городских режимов и лежащих в их основе властных коалиций важно для объяснения динамики городской политики, для анализа механизмов принятия решений и для исследования возможностей, которыми располагают участники городских конфликтов.

В статье мы показываем вариацию городских режимов во всех российских городах-миллионниках (за исключением Москвы и Санкт-Петербурга из-за их особого статуса) и предлагаем их типологию. Ключевая идея типологии-это оценка степени конкуренции политических и экономических 
групп в городе. Для типологии городских режимов мы используем критерии степени фрагментации бизнеса и степени политической конкуренции.

\section{Городские режимы и национальные контексты}

Концепт городского режима предполагает существование устойчивой коалиции, которая, мобилизуя совместные ресурсы, формирует повестку дня. Этот концепт объясняет, почему даже при смене локальных политических элит в результате выборов, доминирующая городская повестка воспроизводится. Первые типологии городских режимов созданы на материале американских городов (Logan, Molotch 1987). Кларенс Стоун предложил классификацию режимов в зависимости от их целей: режим развития, когда городская власть и местный бизнес инвестируют ресурсы в экономический рост; режим поддержания статуса-кво, ориентированный на существующий уровень обеспечения публичными благами; прогрессивный режим, ориентированный на участие в политике среднего класса; режим, нацеленный на расширение возможностей помощи бедным за счет реализации государственных программ (Stone 1989).

Исследования городских режимов в европейских городах привели к модификации концепта с учетом большей роли государства, более низкой административной и финансовой автономии локального уровня, а также государственного финансирования электоральных кампаний (Davies 2003; Harding 1991). Эти факторы ограничивают стимулы к формированию городских режимов по американскому типу: в отличие от крупных американских городов, которые сталкиваются с необходимостью постоянного поиска ресурсов для развития и вынуждены формировать коалиции с местным бизнесом, европейские города гораздо больше зависят от государства в финансовом плане (Pierre 2014). Соответственно, европейские городские режимы более ориентированы на оказание услуг и потребление, чем на развитие (Mossberger, Stoker 2001).

В России политическая децентрализация в 1990-е гг. и необходимость решать социальные и экономические проблемы собственными силами создали коалиций бизнеса и власти в регионах, для описания которых появилось понятие регионального режима (Гельман и др. 2000). Позже проводились исследования городских режимов как в малых (Чирикова, Ледяев 2015), так и в крупных городах, где они осмыслялись как «машины роста» (Тев 2006). Владимир Гельман и Ольга Бычкова (2010) показали, что городские режимы различаются в зависимости от объема политических и экономических ресурсов участников коалиций.

Процессы централизации власти, начавшиеся в нулевые годы, привели к унификации локальных политических порядков. Выстраивание управленческой вертикали вызвало сжатие поля конкурентной политики и повлекло за собой необходимость обеспечивать поддержку партии 
власти. Однако федеральные власти в поиске селективных стимулов для принятия локальными элитами новых правил игры, оставляли последним поле для маневра, что сохраняло сложившееся ранее режимное разнообразие в городах (Гельман, Рыженков 2010).

Как и в случае европейских городов, низкий уровень локальной политической и экономической автономии российских городов создает ряд ограничений для их изучения с точки зрения городских режимов. Зависящие от трансфертов города, когда сама система бюджетного распределения сокращает стимулы для поиска источников экономического роста (Zhuravskaya 2000), не так сильно заинтересованы в создании коалиций, нацеленных на самостоятельное решение внутригородских проблем. Экономический рост городов не конвертируется в увеличение доходов городских бюджетов, что обусловлено системой перераспределения финансов в стране (Стрелка 2019).

В отличие от американских и европейских, российские городские режимы существуют в контексте, где локальной власти необходимо поддерживать авторитарный политический порядок, что серьезно сокращает возможности разнообразия городских режимов. Кроме того, мы ожидаем, что необходимость обеспечивать сохранение авторитарного порядка обусловит доминирование политически неконкурентных режимов, где местный бизнес будет ключевой опорой партии власти (Szakonyi 2020). В отдельных случаях ожидается, что местная специфика или наличие ресурсных игроков может создавать условия для ограниченной конкуренции. В таких случаях локальный бизнес может быть ассоциирован не с партией власти, но с другими системными партиями. Наконец, мы предполагаем, что в основе режимных коалиций будут находиться застройщики и другие экономические группы, наиболее заинтересованные в использовании городских рынков и принятии благоприятных городских решений. Поскольку российские городские режимы не имеют разнообразия консолидированных целей, мы считаем важным обратить внимание на состав городских элит, определяющих динамику городской политики.

\section{Основания типологии: фрагментация бизнеса и политическая конкуренция}

Конфигурация элит, их альянсы и расколы являются частью структуры политических возможностей и определяют шансы на успех действий активистов (McAdam 1996; Goldstone, Tilly 2001). Поэтому в качестве основания типологии городских режимов мы выбираем степень фрагментации элит в составе городских коалиций. Под коалицией в данном случае нами понимается совокупность политических и бизнес-групп, которые представлены в городской ассамблее.

Первое измерение фрагментации- фрагментация бизнеса. Консолидация бизнеса и наличие интегрированной коалиции-предпосылка формирования ориентированного на бизнес городского режима (John, Cole 
1998), в котором наличие разрозненных бизнес-групп, связанных с разными сферами экономики, может ослаблять городской режим (De Socio 2007). В нашем случае фрагментированным бизнес является тогда, когда есть две и более крупных сопоставимых групп депутатов (от шести человек- минимальное данное в законе количество депутатов для образования фракции), представляющих разные сферы бизнеса, или, наоборот, в составе городской ассамблеи нет ни одной такой группы. Если в составе ассамблеи есть одна группа, представляющая интересы предприятий одной отрасли, такое представительство бизнеса будет являться нефрагментированным.

В составе коалиций мы учитывали как местный (мобильный и немобильный), так и неместный немобильный бизнес, имеющий экономические интересы в городе. К неместному немобильному бизнесу мы относили не имеющие местной регистрации предприятия, которые владеют немобильными активами на территории города, например коммунальными сетями. Немобильный бизнес, будучи связанным с городскими правилами игры и городскими рынками, заинтересован в выстраивании отношений с местной властью (Kilburn 2004). В составах коалиций мы учитываем строительный бизнес, частные предприятия в сфере ЖКХ, промышленные предприятия. Кроме того, к бизнес-коалиции мы относим и предприятия, оказывающие «услуги для города», для которых их сбыт связан с функционированием городских рынков, благоустройством городского пространства, а также предоставлением услуг органам власти, социальным бюджетным учреждениям. В ту же категорию вклечены муниципальные предприятия, обеспечивающие функционирование городских сервисов. Мы также обращаем внимание на соотношение в составе городских законодательных ассамблей депутатов от бизнеса и представителей социальной сферы, политики или других некоммерческих сфер. Полагаем, что перевес соотношения в сторону бизнеса отражает ориентированность режима на интересы коммерческих предприятий, входящих в состав ассамблеи.

Второе измерение фрагментации- политическая конкуренция. Степень концентрации власти задает логику развития конфигурации политических и экономических акторов и является важным источником вариации городских режимов. Политическая конкуренция измеряется количеством депутатов в городском совете, которые представляют партию власти «Единая Россия». К режимам с политической конкуренцией мы относим те, в которых в городской ассамблее доля «Единой России» составляет менее 70 \% мандатов. Такая отметка выбрана на том основании, что в современных авторитарных режимах доминирование партии власти безусловно, но оппозиция имеет возможность навязывать ограниченную конкуренцию, что формирует более сложный баланс сил, хотя и не размывает базовые условия легитимности авторитарного порядка (Golosov 2017). Кроме того, для описания степени политической конкуренции городского режима мы учитываем членство депутатов-представителей бизнеса в «Единой России». 
Наш анализ основан на эмпирическом материале из 14 российских городов-миллионников, для которых мы анализируем тип коалиции, определяющей характер городского режима. Рассмотрены данные о составе городских представительных органов за один созыв. Мы используем материалы СМИ и экспертных сообщений. Ограничением нашего метода является то, что он фокусируется лишь на формальном представительстве в городских ассамблеях, оставляя за скобками многие неформальные механизмы влияния на городские процессы. Вместе с тем городские ассамблеи остаются коллегиальными органами, которые играют ключевую роль во многих городских вопросах. Мы допускаем, что городские акторы, желающие повлиять на городскую повестку и решения, будут заинтересованы в представительстве в городской ассамблее, и ее состав будет в значительной степени отражать характер коалиции, которая лежит в основе городского режима. Мы выбирали состав городских ассамблей для созывов, которые уже завершились или работают последний год (с 2012 по 2020 гг.), чтобы оценить расклад сил и результаты взаимодействий без поправок на текущие политические процессы.

Наша аналитическая модель типологии городских режимов представлена в табл. 1, распределение городов по типам городских режимовв табл. 2. В состязательном режиме с высокой степенью политической конкуренции и высокой степенью фрагментации бизнеса ассамблеи выступают институтами согласования интересов как политических, так и бизнес-групп. Это задает динамический характер политической жизни и создает необходимость поиска баланса между группами бизнеса, стремящихся влиять на городской политический курс в своих интересах, и компромиссов для обеспечения политической управляемости городской жизни.

Таблица 1

Аналитическая модель типологии

Типология городских режимов в российских миллионниках в 2010-е гг.

Степень фрагментации бизнеса в городской ассамблее

\begin{tabular}{l|l|l|l}
\hline \multicolumn{2}{l|}{} & Фрагментированный & Нефрагментированный \\
\hline $\begin{array}{l}\text { Степень } \\
\begin{array}{l}\text { политической } \\
\text { конкуренции }\end{array}\end{array}$ & Конкурентный & $\begin{array}{l}\text { Состязательный } \\
\text { режим }\end{array}$ & $\begin{array}{l}\text { Конфронтационный } \\
\text { режим }\end{array}$ \\
\cline { 2 - 4 } & Неконкурентный & $\begin{array}{l}\text { Соревновательный } \\
\text { авторитарный } \\
\text { порядок }\end{array}$ & $\begin{array}{l}\text { Закапсулированный } \\
\text { режим }\end{array}$ \\
\hline
\end{tabular}


Таблий 2

Распределение российских городов-миллионников по типам городских режимов

\begin{tabular}{|c|c|c|c|}
\hline \multicolumn{4}{|c|}{ Степень фрагментации бизнеса в городской ассамблее } \\
\hline & & Фрагментированный & Нефрагментированный \\
\hline \multirow[t]{2}{*}{$\begin{array}{l}\text { Степень } \\
\text { политической } \\
\text { конкуренции }\end{array}$} & Конкурентный & $\begin{array}{l}\text { Екатеринбург } \\
\text { (2013-2018)* }\end{array}$ & $\begin{array}{l}\text { Красноярск } \\
(2013-2018) \\
\text { Новосибирск } \\
(2015-2020) \\
\text { Омск } \\
(2012-2017)\end{array}$ \\
\hline & Неконкурентный & $\begin{array}{l}\text { Краснодар } \\
(2015-2020) \\
\text { Ростов-на-Дону } \\
(2015-2020) \\
\text { Волгоград } \\
(2013-2018) \\
\text { Самара } \\
(2015-2020) \\
\text { Уфа } \\
(2016-2021) \\
\text { Челябинск } \\
(2014-2019) \\
\text { Казань } \\
(2015-2020)\end{array}$ & $\begin{array}{l}\text { Воронеж } \\
(2015-2020) \\
\text { Пермь } \\
(2016-2021) \\
\text { Нижний Новгород } \\
(2015-2020)\end{array}$ \\
\hline
\end{tabular}

\footnotetext{
* В скобках указаны годы работы проанализированных созывов ассамблей.
}

К состязательному режиму мы относим Екатеринбург (2013-2018 гг.). В составе ассамблеи очевидно преобладание бизнеса (23 депутата) в сравнении с другими акторами (семь депутатов). Фрагментированность бизнеса в ассамблее Екатеринбурга обеспечивалась двумя крупными группами представителей строительной сферы и сферы ЖКХ. При этом пять представителей ЖКХ из шести- депутаты от «Справедливой России», шестой представляет «Единую Россию». Застройщики в составе городской думы Екатеринбурга еще более фрагментированы: из семи представителей четверо связаны с «Единой Россией», двое- со «Справедливой Россией», и одинс КПРФ. Такое положение указывает и на фрагментированность бизнеса и высокую степень политической конкуренции. На примере строительной сферы и ЖКХ в составе городской ассамблеи видно, что городские бизнесэлиты здесь не составляют монолитную конструкцию, ориентированную на лояльность и подотчетность вышестоящим уровням власти. Они рас- 
сматривают свое политическое участие как повод для торга и обмена ресурсами, поскольку принятие решений по профильным вопросам требуют переговоров и учета баланса интересов ключевых акторов. Даже представители промышленности в составе городской думы Екатеринбурга аффилированы с тремя разными политическими партиями. Екатеринбург-это единственный пример конкурентного и фрагментированного режима. Это подтверждает описанное в литературе снижение политической состязательности на местном уровне, вызванное встраиваемостью городских политий в «вертикаль власти», бюджетной зависимостью и институциальными трансформациями в виде отмены прямых выборов мэров (Гилёв и др. 2017).

Случаи Красноярска (2013-2018), Новосибирска (2015-2020) и Омска (2012-2017) относятся к конфронтационному режиму с высокой степенью политической конкуренции и нефрагментированным бизнесом. В этом типе режима есть доминирующая группа бизнеса в составе ассамблеи, но она вынуждена искать баланс интересов с различными силами, имеющими представительство. Конфронтационный режим имеет склонность к монополизации городской политики доминирующей группировкой (через «захват» профильных комиссий), однако сложный политический состав ассамблеи способен ее сгладить.

В Новосибирске фиксируется картельный политический сговор между «Единой Россией» и КПРФ (Перцев 2020а), однако в горсовете представлены и независимые депутаты. Выделяется фракция застройщиков из 16 депутатов, влияющая на формирование градостроительной политики, правил и процедур финансирования коммуникаций и социальной инфраструктуры, экологической политики и др. (Холявченко 2019). Из 16 застройщиков-депутатов десять относились к «Единой России», трое к КПРФ, один к «Справедливой России» и один самовыдвиженец. Несмотря на сближение «Единой России» и КПРФ, ситуация, когда две крупные партии должны договариваться между собой и торговаться за обоюдовыгодные условия, создает пространство для более сложной и конкурентной политической жизни в городе. Однако нефрагментированность бизнес-групп в ассамблее и доминирование представителей строительной отрасли закрывает доступ внешних акторов к выработке и принятию городского политического курса. В Новосибирске доминирование депутатов-строителей негативно сказывалось на развитии самой жилищной сферы, проблемах с правами граждан и проблемах обманутых дольщиков (Холявченко 2019).

Красноярск обладает высокой конкуренцией на политическом уровне: «Единая Россия» имела только треть мандатов в горсовете, а с точки зрения фрагментированности бизнес-групп наблюдалось преобладание строителей. Отличие Красноярска в меньшем представительстве застройщиков (семь депутатов), но в более выпуклой политической конкуренции. На выборах в горсовет в 2013 г. большинство мест получили «Патриоты России», которые находились под контролем у предпринимателя с криминальным 
прошлым (Перцев 2020b), «Единая Россия» заняла второе место. Партийный аффилиации застройщиков в составе городской ассамблеи Красноярска были более разнообразны: двое связаны со «Справедливой Россией», двое с «Патриотами России», по одному с КПРФ, «Единой Россией» и «Гражданской платформой». Тем не менее строительный бизнес в горсовете влиял на решение экологических вопросов и проведение градостроительной и жилищной политики.

Состязательный авторитарный порядок-самый распространенный с точки зрения отнесенных к нему эмпирических случаев (Краснодар, Ростов-на-Дону, Волгоград, Самара, Уфа, Челябинск и Казань). Тип характеризуется низкой политической конкуренцией и фрагментированностью бизнеса. В городах с таким режимом мы наблюдаем доминирование «Единой России» и конфигурацию нескольких бизнес-групп из разных отраслей или несколько типов бизнесов, в которых не выделяются доминирующие группы. В городах с состязательным авторитарным порядком «Единая Россия» имела от 77,7\% мандатов (Уфа) до 96\% (Челябинск). За исключением Самары, мы наблюдаем однозначный перевес представленности бизнеса в соотношении с другими сферами. Он особенно заметен в Уфе - 30 депутатов от бизнеса против восьми небизнесменов. Тогда как в Челябинске и Казани депутатов-бизнесменов в два раза больше, чем других депутатов. В Самаре перевес, напротив, в пользу небизнесменов в составе думы: 20 против 17. В Краснодаре, Челябинске, Уфе и Казани бизнес фрагментирован (две-три группы): в Краснодаре это застройщики и «услуги для города», в Челябинске- строительный бизнес, «услуги для города» и промышленность, в Уфе- застройщики и промышленники, в Казани - ЖКХ, «услуги для города» и промышленность. В Ростове-наДону, Волгограде и Самаре ассамблеи фрагментированы, что выражается в отсутствии доминирующих групп от бизнеса одной отрасли.

В городской думе Краснодара доминируют застройщики и бизнес «услуг для города», что отражает динамичное развитие самого города, численность которого за десять лет выросла вдвое. Активное участие строительного бизнеса в управлении городом связано с высокой конкурентностью рынка и необходимостью доступа бизнеса к ресурсам городского развития - земле и инфраструктуре. В рассматриваемом созыве городской ассамблеи представлены крупнейшие строительные фирмы города и региона. При такой представленности застройщиков Краснодар занимает второе место в России по проблеме обманутых дольщиков (РБК 2020), а «ЮгСтройИнвест» является одной из самых проблемных компаний в этом вопросе (Абрамова 2019).

Похожая ситуация в Уфе, где в составе ассамблеи выделяются две бизнес-группы: десять депутатов от застройщиков и шесть от промышленности. Широкая представленность строителей отражает структуру профильного рынка и конкуренцию между застройщиками. С другой 
стороны, отсутствие политической конкуренции можно описать через категории сговора и неформальных договоренностей. В отличие от Краснодара, представленность «Единой России» в Уфе чуть ниже и среди застройщиков есть депутаты, аффилированные с КПРФ и «Патриотами России». Однако доминирование отраслевого бизнеса в Уфе не создает условия для открытости системы власти и представительства интересов горожан. Актуальная для Уфы проблема точечной застройки (Шахов 2020) показывает, что превалирование интересов бизнеса может быть доведено до предела и снятие напряженности в противостоянии граждан и застройщиков возможно при участии главы региона.

Последний тип городского режима, который мы называем закаncyлированным, характеризуется нефрагментированностью бизнеса в составе ассамблеи и низкой политической конкуренцией. К этому типу мы относим Воронеж (2015-2020), Нижний Новгород (2015-2020) и Пермь (2016-2021). Сочетание зависимого от городских ресурсов бизнеса, доминирующего в ассамблее с партией власти, следящей за устойчивостью авторитарного порядка посредством элитных договоренностей, не располагает к открытому согласованию интересов широкого круга участников городской политики. В Перми главенствующим бизнесом являются строительные компании, а в Воронеже и Нижнем Новгороде- «услуги для города». Пермский случай примечателен тем, что среди шести депутатов-застройщиков в городской думе три мандата принадлежат представителям одной строительной компании-ПЗСП, входящим в управляющие органы «Единой России», а также в профильный комитет думы по градостроительству. Такое масштабное представительство не только отраслевого бизнеса, но одной строительной фирмы в городской думе при поддержке партии власти часто приводило к конфликту интересов, когда депутаты принимали институциальные решения в интересах развития своего бизнеса или не принимали решения в интересах их конкурентов (Русских 2020).

Доминирование бизнеса «услуги для города» при преобладании «Единой России» в Нижнем Новгороде является отражением режима, завязанного на роли губернатора в вопросах развития. Губернатор после занятия должности инициировал перераспределение полномочий в градостроительной сфере от муниципалитетов в пользу регионального уровня (Деловой квартал 2017). Он сформулировал видение развития городской среды, в которой особое место отдавалось модернизации инфраструктуры и созданию условий для покупки лояльности городского среднего класса. Доминирование в гордуме ориентированного на городские услуги бизнеса позволило добиться быстрого принятия соответствующих нормативных решений. Конфликтная проблема сохранения исторической застройки частично купирована за счет включения этой проблемы в приоритеты градостроительной деятельности властей, при этом бизнес получил дополнительные возможности для участия в ее реализации (Елфимова 2020). 


\section{Заключение}

В большинстве городов-миллионников мы наблюдаем политически неконкурентные городские режимы с различной степенью фрагментации бизнеса, в которых бизнес преимущественно связан с партией власти. Исключение составляют случаи, где присутствует политическая конкуренция и фрагментация бизнеса (Екатеринбург) или где политическая конкуренция сочетается с доминированием одной бизнес-группы: застройщиков в Новосибирске и Красноярске и крупных промышленников в Омске.

Застройщики присутствуют в составах ассамблей всех городов-миллионников, но мы видим вариацию групп от небольших в два-четыре депутата до доминирующих как в Новосибирске или Уфе. Застройщики являются важными акторами в политических процессах в российских городах и их представительство в городских ассамблеях везде обязательно, однако далеко не везде строительный бизнес имеет значительный или однозначный контроль за городской повесткой. Это происходит, прежде всего, там, где застройщикам удалось сформировать большую фракцию или контролировать профильную комиссию (Новосибирск, Уфа, Пермь) или там, где наблюдается резкий рост строительного рынка (Краснодар). Другие значимые группы бизнеса-это те, кто оказывает т.н. услуги для города, бизнес, ориентированный на сбыт товаров и услуг, связанных с городскими вопросами, а также представители сферы ЖКХ.

Наши данные не позволяют говорить, насколько продолжительно существование городских режимов и насколько регулярно воспроизводятся структуры коалиций в городах-миллионниках. Вместе с тем проанализировав партийную принадлежность бизнеса, представленного в ассамблеях, мы можем утверждать, что за некоторыми исключениями, такие депутаты представляют партию власти, очевидно рассматривая этот союз как способ обменять свою политическую лояльность на экономические преференции. Этот принцип, лежащий в основе большинства городских режимов, является весьма устойчивым в условиях авторитарного порядка, и поддерживает их воспроизводство. А там, где местный крупный бизнес готов поддержать другие политические силы, как в Екатеринбурге, возможно складывание более политически конкурентного режима.

Предложенная типология российских городских режимов может стать основой для дальнейшего поиска источников их вариации, а также понимания того, какие режимы являются более отзывчивыми к требованиям граждан. Мы допускаем, что тип городского режима может быть связан с тем, насколько город зависит от межбюджетных трансфертов: более зависимые от трансфертов города менее заинтересованы в поддержке бизнеса, который инвестирует в город, но более ориентированы на лояльность в отношении региона или центра. В результате вероятность создания режима, нацеленного исключительно на бизнес, снижается, как и поли- 
тическая конкуренция, и отзывчивость режима к требованиям граждан. Однако к складыванию режимов, ориентированных на бизнес, могут привести динамичное развитие города и его строительного рынка. При этом более развитый и конкурентный рынок может мотивировать застройщиков к участию в политике от разных политических партий, следовательно в таких городах скорее должны складываться конкурентные режимы, реагирующие на требования граждан.

\section{Выражение признательности}

Исследование выполнено за счет гранта Российского научного фонда (проект РНФ № 18-78-10054) «Механизмы согласования интересов в процессах развития городских территорий».

Редакция благодарит программу «Университетское партнерство» за поддержку и возможность опубликовать данную статью.

\section{Материалы для анализа}

Абрамова Р. (2019) «ЮгСтройИнвест» уже не рекомендуют друзьям. И даже врагам не советуют. Доступно по ссылке: https://clck.ru/R9tf4 (дата обращения: 11 сентября 2020).

Деловой квартал (2017) Глава региона снова отнимает у Нижнего Новгорода градострочтельные полномочия. Доступно по ссылке: https://clck.ru/R9tim (дата обращения: 10 сентября 2020).

Елфимова И. (2020) Никитин пообещал сохранить историческую застройку на Сенной. Доступно по ссылке: https://clck.ru/PdeiV (дата обращения: 17 сентября 2020).

Перцев А. (2020а) Смотришь на город и бесишься. Доступно по ссылке: https://clck.ru/ PqJvx (дата обращения: 31 августа 2020).

Перцев А. (2020b) Он бы научил Родину любить. Доступно по ссылке: https://clck.ru/ NM3ре (дата обращения: 31 августа 2020).

РБК (2020) Вечный долгострой: Кубань заняла 2 место в РФ по числу проблемных домов. Доступно по ссылке: https://clck.ru/R9tnX (дата обращения: 12 сентября 2020).

Русских О. (2020) Эскалация по-пермски. Как бизнес-конфликт раздулся до политической конфронтации. Доступно по ссылке: https:/clck.ru/R9ton (дата обращения: 14 сентября 2020).

Стрелка (2019) Экономика городов-миллионников: право на развитие. Доступно по ссылке: https://media.strelka-kb.com/gdpcities (дата обращения: 17 сентября 2020).

Холявченко Д. (2019) Новосибирск на пороге краха строительного рынка. Доступно по ссылке: https://clck.ru/R9tv7 (дата обращения: 29 августа 2020).

Шахов С. (2020) Как в Уфе остановили строительство скандально известного дома. Доступно по ссылке: https:/clck.ru/R9twx (дата обращения: 13 сентября 2020).

\section{Список источников}

Бычкова О., Гельман В. (2010) Экономические акторы и локальные режимы в крупных городах России. Неприкосновенный запас, (2): 73-82.

Гельман В.Я., Рыженков С.И., Бри М. (ред.) (2000) Россия регионов: трансформаиия политических режимов. М.: Весь Мир. 
Гельман В. Я., Рыженков С.И. (2010) Локальные режимы, городское управление и «вертикаль власти» в современной России. ПОЛИТЭКС, 6 (4): 130-151.

Гилёв А.В., Семёнов А.В., Шевцова И.К. (2017) «Политические машины» и их «водители»: электоральное администрирование на местном уровне. Полития, 3 (86): 62-80.

Ледяев В.Г. (2006) Социология власти: теория городских политических режимов. Сочиологический журнал, (3-4): 46-68.

Пустовойт Ю. А. (2019) Как создается режим: властные коалиции в сибирских городах. Полис, (4): 104-118.

Тев Д.Б. (2006) Политэкономический подход в анализе местной власти. К вопросу о коалиции, правящей в Санкт-Петербурге. ПОЛИТЭКС, 2 (2): 99-121.

Тыканова Е.В., Хохлова А.М. (2015) Городской политический режим в Санкт-Петербурге: роль реальных и воображаемых «машин роста» в борьбе за городское пространство. Журнал исследований социальной политики, 13 (2): 241-256.

Чирикова А.Е., Ледяев В.Г. (2015) Власть в малых российских городах: модели взаимодействия исполнительной и представительной власти. Мир России, 24 (3): 6-32.

Чирикова А.Е., Ледяев В.Г. (2019) Конфигурация основных акторов в малом российском городе и лидерство: векторы перемен. Власть и элиты, 6 (1):216-238.

Davies J. S. (2003) Partnerships Versus Regimes: Why Regime Theory Cannot Explain Urban Coalitions in the UK. Journal of Urban Affairs, 25 (3): 253-270.

De Socio M. (2007) Business Community Structures and Urban Regimes: A Comparative Analysis. Journal of Urban Affairs, 29 (4):339-366.

Goldstone J. A., Tilly C. (2001) Threat (and Opportunity): Popular Action and State Response in the Dynamics of Contentious Action. In: R. Aminzade, J. Goldstone, D. McAdam, J. Perry, S. Tarrow, W. Sewell, C. Tilley (eds.) Silence and Voice in the Study of Contentious Politics. Cambridge: Cambridge University Press: 179-194.

Golosov G. V. (2017) Authoritarian Learning in the Development of Russia's Electoral System. Russian Politics, 2 (2): 182-205.

Harding A. (1991) The Rise of Urban Growth Coalitions, UK-style? Environment and Planning C: Government and Policy, 9 (3):295-317.

John P., Cole A. (1998) Urban Regimes and Local Governance in Britain and France: Policy Adaption and Coordination in Leeds and Lille. Urban Affairs Review, 33 (3):382-404.

Kilburn H. W. (2004) Explaining U. S. Urban Regimes: A Qualitative Comparative Analysis. Urban Affairs Review, 39 (5): 633-651.

Logan J. R., Molotch H. L. (1987) Urban Fortunes: The Political Economy of Place. Berkeley: University of California Press.

McAdam D. (1996) Conceptual Origins, Current Problems, Future Directions. In: D. McAdam, J.D. McCarthy, M.N. Zald (eds.) Comparative Perspectives on Social Movements: Political Opportunities, Mobilizing Structures, and Cultural Framings. Cambridge: Cambridge University Press: 23-40.

Mossberger K., Stoker G. (2001) The Evolution of Urban Regime Theory: The Challenge of Conceptualization. Urban Affairs Review, 36 (6): 810-835.

Pierre J. (2014) Can Urban Regimes Travel in Time and Space? Urban Regime Theory, Urban Governance Theory, and Comparative Urban Politics. Urban Affairs Review, 50 (6): 864-889.

Szakonyi D. (2020) Politics for Profit: Business, Elections, and Policymaking in Russia. Cambridge: Cambridge University Press.

Stone C. N. (1989) Regime Politics: Governing Atlanta, 1946-1988. Lawrence: University Press of Kansas.

Zhuravskaya E. (2000) Incentives to Provide Local Public Goods: Fiscal Federalism, Russian Style. Journal of Public Economics, 76 (3): 337-368. 
Vsevolod Bederson, Irina Shevtsova

\title{
DEVELOPERS, THE PARTY OF POWER AND A BIT OF COMPETITION IN RUSSIA'S MILLION-PLUS CITIES: A TYPOLOGY OF URBAN REGIMES IN THE 20105
}

\begin{abstract}
The quality of interaction among key urban actors, which is described by the concept of an urban regime, is a significant structural factor influencing the logic of urban conflicts. Definitions of urban regime are based on the prerequisite that cities possess large political and economic autonomy, which is a key indicator in the appearance of an urban regime appearance. Large cities in Russia exist in an authoritarian context and strongly depend on higher-level authorities. This dependence predictably reduces opportunities for the shaping of specific urban regimes. At the same time, large cities remain leading resource centres, maintaining their political, economic, and social diversity, which leads to diversity in urban regimes across Russia, especially in the extent of political competition and range of urban actors. In the article, we show a variety of urban regimes in all Russia's million-plus cities (except for Moscow and St. Petersburg), offering a typology to categorize them. The analysis is based on data of local assemblies' compositions in 2012-2020 as well as on media reports. The basic idea of the typology is based on an assessment of the degree of competition between political and economic groups. We proceed from the premise that competition is a key factor boosting the responsiveness of authorities and expanding opportunities for urban conflict participants. For the typology, we use two criteria: both the extent of business group fragmentation and political competition. In most of Russia's millionplus cities, we reveal politically non-competitive urban regimes with fragmented ('competitive authoritarian arrangement') or non-fragmented business ('encapsulated urban regime'), in which business is mostly associated with the party of power. In only one case political competition remains along with a diversity of business groups ('competitive urban regime') and in some cases, political competition is combined with the domination of one business group ('confrontational urban regime').
\end{abstract}

Key words: local regimes, local politics, conflicts, business, party of power

DOI: 10.17323/727-0634-2021-19-2-285-300

\footnotetext{
Vsevolod Bederson- Cand. Sci. (Polit.), Senior Research Associate, Sociological Institute of the RAS - Branch of the Federal Center of Theoretical and Applied Sociology of the Russian Academy of Sciences; Senior research fellow, Center of Comparative History and Politics, Perm State University, Perm, Russian Federation. Email: vsbederson@gmail.com

Irina Shevtsova- Cand. Sci. (Polit.), Senior Research Associate, Sociological Institute of the RAS - Branch of the Federal Center of Theoretical and Applied Sociology of the Russian Academy of Sciences; Director, Center of Comparative History and Politics, Perm State University, Perm, Russian Federation. Email: irinashevtsova@comparativestudies.ru
} 


\section{References}

Bychkova O., Gel'man V. (2010) Ekonomicheskie aktory i lokal'nye rezhimy v krupnykh gorodakh Rossii [Economic Actors and Local Regimes in Large Cities of Russia]. Neprikosnovennyy zapas [Emergency Ration], (2): 73-82.

Chirikova A.E., Ledyaev V.G. (2015) Vlast' v malykh rossiyskikh gorodakh: modeli vzaimodeystviya ispolnitel'noy i predstavitel'noy vlasti [Power in Small Russian Cities: Models of Interaction between Executive and Representative Power]. Mir Rossii [Universe of Russia], 24 (3): 6-32.

Chirikova A.E., Ledyaev V.G. (2019) Konfiguracija osnovnyh aktorov v malom rossijskom gorode i liderstvo: vektory peremen [Configuration of the Main Actors in a Small Russian City and Leadership: Vectors of Change]. Vlast' i jelity [Power and Elites], 6 (1):216-238.

Davies J. S. (2003) Partnerships Versus Regimes: Why Regime Theory Cannot Explain Urban Coalitions in the UK. Journal of Urban Affairs, 25 (3):253-270.

De Socio M. (2007) Business Community Structures and Urban Regimes: A Comparative Analysis. Journal of Urban Affairs, 29 (4): 339-366.

Gel'man V. Ya., Ryzhenkov S. I., Bri M. (red.) (2000) Rossiya regionov: transformatsiya politicheskikh rezhimov [Russia of Regions: Transformation of Political Regimes]. Moscow: Ves' Mir.

Gel'man V. Ya., Ryzhenkov S.I. (2010) Lokal'nye rezhimy, gorodskoe upravlenie i 'vertikal' vlasti' v sovremennoy Rossii [Local Regimes, Urban Governance and the 'Vertical of Power' in Modern Russia]. POLITEKS [Political Expertise], 6 (4): 130-151.

Gilev A. V., Semenov A. V., Shevtsova I.K. (2017) 'Politicheskie mashiny' i ikh 'voditeli': elektoral'noe administrirovanie na mestnom urovne ['Political Machines' and Their 'Drivers': Electoral Administration at the Local Level]. Politiya [Politea], 3 (86): 62-80.

Goldstone J.A., Tilly C. (2001) Threat (and Opportunity): Popular Action and State Response in the Dynamics of Contentious Action. In: R. Aminzade, J. Goldstone, D. McAdam, J. Perry, S. Tarrow, W. Sewell, C. Tilley (eds.) Silence and Voice in the Study of Contentious Politics. Cambridge: Cambridge University Press: 179-194.

Golosov G. V. (2017) Authoritarian Learning in the Development of Russia's Electoral System. Russian Politics, 2 (2): 182-205.

Harding A. (1991) The Rise of Urban Growth Coalitions, UK-style? Environment and Planning C: Government and Policy, 9 (3):295-317.

John P., Cole A. (1998) Urban Regimes and Local Governance in Britain and France: Policy Adaption and Coordination in Leeds and Lille. Urban Affairs Review, 33 (3):382-404.

Kilburn H. W. (2004) Explaining U. S. Urban Regimes: A Qualitative Comparative Analysis. Urban Affairs Review, 39 (5): 633-651.

Ledyaev V.G. (2006) Sotsiologiya vlasti: teoriya gorodskikh politicheskikh rezhimov [The Sociology of Power: A Theory of Urban Political Regimes]. Sotsiologicheskiy zhurnal [Sociological Review], (3-4): 46-68. 
Logan J. R., Molotch H. L. (1987) Urban Fortunes: The Political Economy of Place. Berkeley: University of California Press.

McAdam D. (1996) Conceptual Origins, Current Problems, Future Directions. In: D. McAdam, J.D. McCarthy, M. N. Zald (eds.) Comparative Perspectives on Social Movements: Political Opportunities, Mobilizing Structures, and Cultural Framings. Cambridge: Cambridge University Press: 23-40.

Mossberger K., Stoker G. (2001) The Evolution of Urban Regime Theory: The Challenge of Conceptualization. Urban Affairs Review, 36 (6): 810-835.

Pierre J. (2014) Can Urban Regimes Travel in Time and Space? Urban Regime Theory, Urban Governance Theory, and Comparative Urban Politics. Urban Affairs Review, 50 (6): 864-889.

Pustovoyt Yu.A. (2019) Kak sozdaetsja rezhim: vlastnye koalicii v sibirskih gorodah [How the Regime is Created: Power Coalitions in Siberian Cities]. Polis, (4): 104-118.

Stone C. N. (1989) Regime Politics: Governing Atlanta, 1946-1988. Lawrence: University Press of Kansas.

Szakonyi D. (2020) Politics for Profit: Business, Elections, and Policymaking in Russia. Cambridge: Cambridge University Press.

Tev D. B. (2006) Politekonomicheskiy podkhod v analize mestnoy vlasti. K voprosu o koalitsii, pravyashchey v Sankt-Peterburge [Political Economic Approach in the Analysis of Local Government. On the Question of the Coalition Ruling in St. Petersburg]. POLITEKS [Political Expertise], 2 (2): 99-121.

Tykanova E. V., Khokhlova A.M. (2015) Gorodskoy politicheskiy rezhim v Sankt-Peterburge: rol' real'nykh i voobrazhaemykh 'mashin rosta' v bor'be za gorodskoe prostranstvo [Urban Political Regime in St. Petersburg: the Role of Real and Imaginary 'Growth Machines' in the Struggle for Urban Space]. Zhurnal Issledovanii Sotsial'noi Politiki [Journal of Social Policy Research], 13 (2):241-256.

Zhuravskaya E. (2000) Incentives to Provide Local Public Goods: Fiscal Federalism, Russian Style. Journal of Public Economics, 76 (3): 337-368. 